\title{
JOURNAL.RU
}

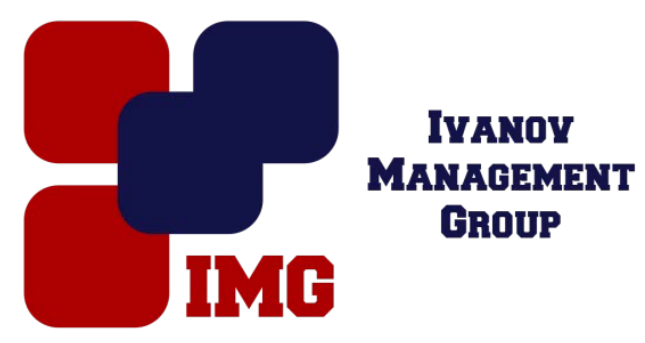

Чернопятов А.М., Бондарева Е.И. Сургутский государственный педагогический университет

Сургут, Россия

doi: 10.18411/lj-31-01-2017-2-09

idsp 000001:lj-31-01-2017-2-09

\section{Инкорпорирование профессиональных стандартов в систему образовательных услуг}

\section{Аннотация}

В статье авторами рассматриваются проблемы и пути инкорпорирования профессиональных стандартов в деятельность учебных заведений. Задача профессиональных стандартов состоит в улучшении оказания образовательных услуг, направленных на повышение качества выпускников. Требования рынка труда к выпускникам постоянно растет и соответственно должна постоянно модернизироваться база учебных заведений.

Ключевые слова: компонента, управление, программа, образование, компетентность, качества.

\section{Abstract}

In the article, the authors discuss the problems and ways of incorporating professional standards into the activities of educational institutions. The goal of professional standards is to improve the provision of educational services aimed at improving the quality of graduates. The requirements of the labour market for graduates is growing and thus need to constantly upgrade base of educational institutions.

Keywords: component, control, program, education, competence, quality.

В современных условиях рынок труда перманентно обновляет свои требования к качеству выпускников образовательных учреждений. Задачи, которые ставит работодатель, перед образовательными учреждениями заключаются в том, что будущий специалист должен подходить не только по образовательным характеристикам, но и по психологическим, индивидуальным, управленческим.

Проблемы трудоустройства выпускников образовательных учреждений являются важной социально-экономической компонентой в сложившихся 
условиях. Введенные профессиональные стандарты, которых более 800, должны еще инкорпорироваться в существующую систему образовательных услуг. За этим стоит создание действенных механизмов и инструментов, которые будут обеспечивать эффективную и качественную взаимосвязь между требованиями работодателя и сферой образовательных услуг.

Поэтому, подготавливая специалистов, мы должны в первую очередь опираться на требования рынка труда, требования работодателей, перспективы их трудоустройства с учетом потребностей экономики страны.

Необходима качественная программа по трудоустройству выпускников и это должна в какой-то мере решить профессионально-общественная аккредитация образовательных программ и их соответствия современным требованиям.

Основной целью образовательных учреждений является обучение и подготовка специалиста, который должен обладать определенным набором знаний, навыков, профессиональных и морально-этических качеств. Перечень этих требований к выпускнику высшего учебного заведения сформулирован в федеральных государственных образовательных стандартах высшего образования.

Компетенции и компетентность становятся базовыми понятиями нового подхода к содержанию современного образования. Существует много определений понятия компетенция и компетентность.

А.А. Карманова [5] ключевые компетенции описывала как целостную систему универсальных знаний, умений, навыков, а также опыта самостоятельной жизнедеятельности и личной ответственности обучающихся.

Э. Шорт [6] дает такое определение «компетенции» - «владение ситуацией в условиях из меняющейся окружающей среды, способность реагировать на воздействие среды и изменять ее».

Т. Е. Исаева [2] утверждает, что компетенции - это сложное явление, определенное качество восприятия человеком действительности, которое подсказывает наиболее эффективный способ решения жизненных ситуаций. Особенностью компетенции является способность личности использовать полученные знания, умения, создавать новые смыслы, информацию, объекты действительности в процессе непрерывного личностного самосовершенствования.

В работах Дж. Равена [3] термин "компетентность" определяется как специфическая способность эффективного выполнения конкретных действий в предметной области, включая узкопредметные знания, особого рода предметные навыки, способы мышления, понимание ответственности за свои действия.

A.В. Хуторский [7] понимает "компетенцию" как требование к образовательный подготовке обучаемого, а компетентность - определенное качество личности обучаемого и минимальный опыт по отношению к деятельности в заданной сфере. 
У Э.Ф. Зеера [1] компетентность - это целостная и систематизированная совокупность обобщенных знаний, а компетенция - обобщенный способ действий, обеспечивающих продуктивное выполнение профессиональной деятельности, т.е. способность человека на практике реализовывать свою компетентность.

Обобщая вышеизложенные понятия компетенции и компетентности можно отметить, что компетенция - это способность применять знания, умения, успешно действовать на основе практического опыта при решении задач предметной области. Компетентность - это владение совокупностью обобщенных знаний и умениями, которая позволяет выполнять конкретные действия, включая узкопредметные знания, особого рода предметные навыки, способы мышления, понимание ответственности за свои действия.

В настоящее время на первый план выдвигаются новые требования рынка труда к молодым специалистам. На современном рынке труда по-настоящему конкурентоспособным будет такой работник, который владеет способностью среди множества решений выбирать наиболее оптимальное, аргументированно опровергать ложные решения, подвергать сомнению эффектные, но неэффективные решения, т. е. владеть критическим мышлением. Для подготовки специалистов такого уровня высшие учебные заведения должны изменить существующие взаимоотношения с работодателями. В связи с этим особую актуальность приобретает формирования у выпускников профессиональных компетенций на основе взаимосвязи профессионального образования с их будущей деятельностью.

Проблема трудоустройства является важной социально-экономической проблемой, как для всей системы российского профессионального образования, так и для страны в целом. Ее решение состоит в создании механизмов, обеспечивающих эффективную взаимосвязь между рынком труда и рынком образовательных услуг. Готовя будущих специалистов, необходимо учитывать перспективы их дальнейшего трудоустройства на основе реальных потребностей рынка труда. Кроме того, и будущий выпускник образовательного учреждения должен знать возможность трудоустройства после получения той или иной специальности.

Производство требует комплексного применения знаний по различным дисциплинам, а выпускники зачастую не готовы в полной мере решать конкретные проблемы на предприятии. В этом им мешать пропасть между теоретической подготовкой в вузах и практическими аспектами трудовой деятельности, между высоким уровнем подготовки молодых специалистов и требуемым от него соответствующих трудовых умений и навыков со стороны работодателя. Сложившаяся система высшего образования недостаточна гибкая и не обеспечивает быструю адаптацию выпускников к производственным условиям. Имеющийся багаж знаний, умений и навыков используется ими недостаточно, так как отдельно изучаемые дисциплины формируют навыки решения только частных задач данной области[9]. 
Более тесную взаимосвязь обучения с производством может обеспечить взаимосвязанная организация учебного процесса, когда с первого курса обучения студентов знакомят с действительно существующей рабочей обстановкой на производстве, с техникой, приборами, расчётами, документацией, курсовые проекты и выпускные квалификационные работы выполняются по реальной тематике производств.

Поэтому подготавливая специалистов мы должны в первую очередь опираться на требования рынка труда, требования работодателей, перспективы их трудоустройства с учетом потребностей экономики страны.

Необходима качественная программа по трудоустройству выпускников и это должна в какой-то мере решить профессионально-общественная аккредитация образовательных программ и их соответствия современным требованиям [8].

Вследствие вышеперечисленного мы можем констатировать, что инкорпорирование профессиональных стандартов в образовательную сферу, с целью подготовки специалистов на высоком качественном уровне являются актуальными в современных условиях. Одним из современных направлений в области совместимости подготовки и требований является профессиональнообщественная аккредитация образовательных программ (ПОА). С помощью ПОА работодатели могут проверять высшие учебные заведения и колледжи на соответствие профессиональным стандартам. При этом ПОА не дублирует государственную аккредитацию, а наоборот является дополнением к ней и позиционирует образовательное учреждение на более высоком уровне, повышает рейтинг, увеличивает бюджетное ассигнование, усиливает имидж и другое. 


\section{Литература}

1. Зеер Э.Ф. Компетентностный подход к модернизации профессионального образования / Э. Зеер, Э. Сыманюк // Высшее образование в России. - 2005. - № 4. - С. 23 - 30.

2. Исаева, Т.Е. Классификация профессионально-личностных компетенций вузовского преподавателя/ Т.Е. Исаева // Педагогика.-2006.-№9.-С.55-60.

3. Равен Дж. Компетентность в современном обществе. Выявление, развитие и реализация. М., 2002. (англ. 1984).

4. Московская Н.Л. Формирование профессиональной компетентности лингвистапреподавателя: Дис. ...д-ра пед. наук: 13.00.08. - М., 2005.

5. Чернопятов А.М. Применение и развитие дисциплины "маркетинг" в образовании на современном этапе. Образование и наука: современные тренды: коллективная монография. Серия "Научно-методическая библиотека, 2016. С.99-121.

6. Инновационное развитие России: возможности, проблемы, перспективы: Монография; [под. ред. Л.А. Толстолесовой]. Новосибирск: Изд. АНС "СибАК", 2015. 158c.

7. А.В.Хуторской. Определение общепредметного содержания и ключевых компетенций как характеристика нового подхода к конструированию образовательных стандартов». URL: http://www.eidos.ru/journal/2002/0423.htm.

8. Чернопятов А.М. Процессное обучение с применением анализа превосходства//Инновационная экономика: информация, аналитика, прогнозы.-2014.№3.-c. 45

9. Чернопятов А.М. Бенчмаркетинг: Учебное пособие для студентов высш. учеб. заведений.-С.: Издательство ООО "Винчера", 2014.-с.227

10. Чернопятов А.М. Экономическая безопасность страны в свете глобализации экономики// Транспортное дело России. -2015.-№3.-с.18. 